Ana Knezevic Bojovic, Ph.D., Institute of Comparative Law, Serbia

Vesna Coric, Ph.D., Institute of Comparative Law, Serbia

\title{
LEGAL SCIENCE AND REGULATORY REFORM IN SERBIA: ONE STEP FORWARD, TWO STEPS BACK
}

\begin{abstract}
Summary
Governments are faced with a challenge of constant and continuous updating and reforming of regulatory framework in their countries to keep up with the rapidly changing world. Ideally, this process should be underpinned by an evidence-based policy-making approach. Over the past years, Serbia has taken a number of steps in an effort to consolidate the legislative process and ensure a systemic approach founded on evidence-based policy-making, entailing a more prominent role of legal science (and other social sciences) in the policy-making and legislative process. The current paper examines the hypothesis that the Serbian regulatory framework provides strategic incentives for a prominent role of legal science in regulatory reform in Serbia. There is not a univocal definition of "legal science", hence, it is often disputable, whether a particular discipline meets the requirements to fit into the legal science realm. The authors try to address this ambiguity and to coin a tailored definition of legal science, which will serve to determine against which background the hypothesis is examined. The authors apply the broad concept of legal science, which is distinguished from other non-scientific activities in a mode mainly proposed by defenders of the argumentativist model. The authors go on to explore whether the determination of legal science as modelled by the international standards and national regulatory framework of Serbia fits into the definition of the legal science proposed in this paper. A particular emphasis is to be placed on the potential and already achieved opportunity for legal scholars to make social and economic impact through enhancing the quality of national regulatory framework. Further, the authors critically assess the new regulatory framework governing science and research in Serbia from this standpoint, pointing out to the lack of a systemic approach and the "cherry picking" in regulatory solutions. The authors conclude that indicators for assessing the real impact made by activities of legal scholars are not sufficient. Consequently, they offer three different sets of activities that should be clearly included in the notion of legal science and consequently valorised as contributions of legal scholars to the social and economic development.
\end{abstract}

Keywords: legal science, regulatory reform, expected impact, Republic of Serbia

\section{Offering a concept of legal science}

There is no univocal definition of "legal science" despite a recurrent discussion on the issue that has lasted several centuries. ${ }^{1}$ Particularly, it is often disputable

Santiago Nino C. Algunos Modelos Metodológicos de 'Ciencia' Jurídica. México City: Fontamara UNAM, 1999, pp. 9-11. 
whether a particular discipline meets the requirements to fit into the legal science realm. ${ }^{2}$ For the purpose of this paper, we will try to address this ambiguity and to coin a tailored definition of legal science, which will serve to determine against which background we are going to assess whether and to which extent the Serbian regulatory framework provides strategic incentives for a prominent role of legal science in regulatory reform. Herein, the term "regulatory reform" will include the following processes: law-making, policy-making and judicial decision-making. ${ }^{3}$

Given the objective of our analysis, we will rely on the broader definition of legal science. While it is well-established in literature that legal science stricto sensu includes activities directed toward identification of content of law, the legal science ampio sensu has a much broader meaning. For most authors, legal science ampio sensu additionally covers the set of disciplines which have in some sense the law as an object of study. They include, inter alia, science of law, legal theory, jurisprudence, legal dogmatics, the sociology of law, legal anthropology, comparative law, history of law, and science of legislation. ${ }^{4}$ Some authors use the label "legal sciences" in a plural form to refer to all those disciplines that deal with law. ${ }^{5}$ For the purpose of this paper, we opt for the term of legal science in a broader sense.

The recourse to the broader definition is attributable to the fact that all those disciplines should be taken into account when assessing to which extent they play a prominent role in regulatory reform, requiring, inter alia, interpretation of jurisprudence of supranational and foreign courts by authorities, intense reliance on comparative law, as well as examination of history of legal drafting. In doing so, it is important to keep in mind the different views of legal scholars regarding the question of whether certain activities originally performed by legal operators, ${ }^{6}$ such as judicial decision-making and legislative drafting, fall under the legal science realm.

This issue became particularly debatable when the requirement on interconnectivity between the academic and non-academic sectors entered international law. Regardless of the current positive trend in international fora, some authors still distinguish the aforementioned set of activities, which traditionally belongs to legal operators, from the core activities of positive law scholars, arguably trying to raise the wall between them. ${ }^{7}$ According to some of them, the key demarcation criterion should be whether legal system attributes the value of formal source of law to certain

2 Núñez Vaquero A. Five Models of Legal Science. Revus, No. 19, 2013, p. 57.

3 According to the OECD, the regulatory policy is about achieving government's objectives through the use of regulations, laws, and other instruments to deliver better economic and social outcomes and thus enhance the life of citizens and business. See Regulatory Policy Overlook 2018. Available at: https://www.oecd.org/gov/regulatory-policy/oecd-regulatory-policy-outlook-20189789264303072-en.htm [last viewed October 15, 2019].

4 See, for instance, Jori M. Il Metodo Giuridico. Milano: Milano, 1976, p. 4; Ciencia Jurídica A. In: El derecho y la Justicia, Ernesto Garzón Valdés and Francisco Laporta (eds.), Madrid: Trotta, 1996, p. 18.

5 Ferrajoli L. Principia Iuris. Roma: Laterza, 2007, pp. 8, 21, 39.

6 The term "legal operators" is used as an umbrella term for legislators, judges, barristers, and lawyers.

7 See more on the dangers of making sharp delineations between different legal disciplines in Dajović G. Proučavanje prava - pravna nauka, teorija i filozofija. Pravni zapisi [Study of the Law: Legal Science, Legal Theory and Philosophy of Law. Review], No. 2, 2017, pp. 222-248. 
text of legal scholars, ${ }^{8}$ while others point to a different methodology they apply; the third group of authors propose the different scope of the sets of activities as a demarcation criterion. ${ }^{9}$ The second and third approaches do not seem problematic, as long as they refrain from attempting to separate activities of positive legal scholars from their expected impact on society and economy. ${ }^{10}$

The demarcation criterion referring to the value of formal source of law seems inadequate, as it excludes from the realm of legal science any work to which the legal system recognized the value of a formal source of law. This approach actually separates the legal science from its expected and desirable impact on legal and wider social reform, although the latter is at this stage of scientific development envisaged as one of its key objectives. It remains unclear why the representatives of this approach claim that scholarly driven research once accepted and declared by state authorities as an official state document loses its legal science background and importance. That approach seems obsolete, as it comes from the ancient Roman law, whose classification envisages that once a legal system recognizes legal value to the text of legal scholars, it is no longer a science of law but a source of law. ${ }^{11}$

The approach given by the natural law thinkers, however, seems better grounded. Within the natural law framework, Serbian scholars made significant contributions through developing their own line of thinking based on philosophy of justice as a rational conception of natural law centred around the Hexagon of Natural Rights. ${ }^{12}$ In doing so, they followed the view taken by other natural law supporters on pluralism of sources of law, according to which a legal doctrine constitutes a source of law as well as being a part of legal science. ${ }^{13}$

The relevance of legal science contributions to regulatory reform is reaffirmed by numerous authors, such as defenders of argumentativist model, who claim that legal scholars should not be limited to describing the content of positive law, but

8 Tamayo Salmerón R. El derecho y la ciencia del derecho. Mexico, UNAM, 1986.

9 See in this context: Peczenik A. Scientia Juris, Dordrecht: Springer, 2005, p. 2 and Aarnio A. The Rational as Reasonable. Dordrecht: Kluwer, 1987, p. 15.

10 As mentioned before, the second group of authors argue that two set of the aforementioned activities use basically the same methods. However, they stress that positive law scholars in performing a set of "core" scholar research activities are additionally required to meet more qualified requirements amounting to recourse to an empirical demonstration or a practical argumentation. This explanation seems adequate, as it does not undermine the achievement or expected impact of legal science. For the other group of authors, their key distinguishing features derive from the different scope of activities performed by positive law scholars and legal operators. While positive law scholars usually deal with describing standards and generic cases, the work originally performed by legal operators is mostly focused on the particular behaviours. This explanation is not fully justifiable, as it overlooks that, in some cases, the legal science approach shall also take into account the particular behaviours in order to offer best solutions.

11 See Núñez Vaquero A. 2013, p. 60.

12 Perovic S. Neprolaznost Heksagona prirodnog prava. In: Besede sa Kopaopnika [Timeless Hexagon of Natural Law. In: Speeches from Kopaonik], 2001, p. 299. Available at: https://kopaonikschool. org/wp-content/uploads/2019/05/BESEDE-2001.pdf [last viewed December 10, 2019].

13 See Hall Arnold B. Review of the Book: The Nature and the Sources of Law (by John Chipman Grey, New York, Columbia University Press, 1909). The American Political Science Review, Vol. 5, No. 4, 1911, p. 646. 
must also propose solutions for hard cases to which the law clearly does not provide a single right answer. ${ }^{14}$ The defenders of argumentativist model rightly observe that legal scholars should not propose solutions for problematic cases based on their own preferences. Instead, the activity of legal scholars should be governed by the set of values and principles and based on legal reasoning as to justify each of their proposed solutions for hard cases. ${ }^{15}$ Similarly, the theory of legisprudence argues that, to develop an effective law to resolve a social problem, they require a theory to underpin the law. ${ }^{16}$ In the context of determining what legal scholars should do in order to make a proper social and economic impact, we will have a recourse to the given views. In particular, we will take into account the recent approach proposed by Barker who insists on social impact to be made by legal scholars. According to her, valuation of legal academic's excellence should also consider whether or not they are cited in case law, as well as their contributions to fostering knowledge and understanding of law among non-lawyers. ${ }^{17}$ This model is chosen, as it seems to explain the role of legal scholars in impacting the society and economy in most realistic terms. ${ }^{18}$

In the following subsections, it will be firstly explored whether the determination of legal science as modelled by the international standards and national regulatory framework of Serbia fits into the definition of the legal science tailored within this paper. A particular emphasis will be placed on the potential and already achieved results of legal scholars in making social and economic impact through enhancing the quality of national regulatory framework. However, the research will be limited to the contributions brought by legal researchers employed in scientific research organizations (SROs), while excluding the contributions yielded by legal operators

14 The argumentativist model is one of five established models of legal science as determined by the cited author. According to his classification, the other models of legal science ampio sensu are: the normativist model, the realistic model, the technological model and the critical model. See Núñez Vaquero A. 2013, p. 61.

15 See, for instance, Alexy R. The Special Case Thesis. Ratio Juris, Vol. 12, No. 4, 1999, pp. 374-384.

16 See Wintgens J. The Theory and Practice of Legislation: Essays in Legisprudence. Aldershot: Ashgate, 2005. The principle premises of legisprudence are supported and further elaborated in, for example: Seidman R. B. Between Policy and Implementation: Legislative Drafting for Development. In: Drafting Legislation. A Modern Approach, Constantin Stefanou and Helen Xanthaki (eds.), Ashgate e-Book: London, 2008, pp. 287-320; This approach is defended in Serbian legal science, inter alia, by Vasić, who clearly states that legal science sets the requests for those who write the laws, whereas the role of legal drafters is to provide these requests with the proper form and thus ensure they can be implemented. See: Vasić R. Pravna država i vladavina zakona: Šta pravna teorija poručuje nomotehnici. In: Nomotehnika i pravničko rasuđivanje [Legal State and Rule of Law: What Are the Messages Sent by the Legal Science to the Nomotechnics. In: Nomotechnics and Legal Reasoning], Vasić R., Stanković M. (eds.), UNDP i Pravni fakultet Univerziteta u Beogradu, 2018, pp. 17-67. Available at: https://www.rs.undp.org/content/dam/serbia/ Publications\%20and\%20reports/Serbian/DobraUprava/undp_rs_Nomotehnika_Maj2018.pdf.

17 Barker S. Exploring the Development of a Standard System of Citation Metrics for Legal Academics. Canadian Law Library Review, Vol. 43, No. 2, 2018, pp. 11-20.

18 This approach seems to also be supported by Dajovic, who argues that disciplinary division of study of law into legal science, legal theory and empirical legal research is more a question of quantity and methodology than of substance. See: Dajovic G. Proučavanje prava - pravna nauka, teorija i filozofija [Study of the Law: Legal Science, Legal Theory and Philosophy of Law]. Pravni zapisi [Review], No. 2, 2017, p. 239. 
not coming from SROs. It should be noted that in Serbia there is no separate regulatory regime governing legal science, and therefore the paper will outline the regime governing science in general. In the concluding part, the recommendations for improving regulatory frameworks on legal science will be provided along with clarifications for improvement of definition of legal science.

\section{Concept of legal science in Serbia through the lens of international standards}

The interconnectivity between the scientific and non-scientific sectors is a goal recognized by numerous organizations, including the United Nations, ${ }^{19}$ Council of Europe, ${ }^{20}$ and European Union (EU). ${ }^{21}$ However, they are mostly silent on the particular relationships of legal science with regulatory reforms. To better understand the incentives envisaged by international standards for a prominent role of science, and therefore also legal science, in regulatory reform in Serbia, particular attention will be paid to the EU approach toward the aforementioned interconnectivity, given the Serbian status of candidate country.

One of positive features of the EU Research and Innovation Programme is reflected in the requirement to make impact at three different levels: scientific,

19 See Transforming Our World: the 2030 Agenda for Sustainable Development, Resolution adopted by the General Assembly on 25 September 2015 [without reference to a Main Committee (A/70/L.1)]. UNESCO documents in this regard are also relevant.

20 In this context, Article 1 of the Statute of the Council of Europe is relevant, as it states: "This aim shall be pursued through the organs of the Council by discussion of questions of common concern and by agreements and common action in economic, social, cultural, scientific, legal and administrative matters and in the maintenance and further realisation of human rights and fundamental freedoms." See the Statute of the Council of Europe, Council of Europe London, 5.V.1949, European Treaty Series, No. 1. Available at: https://rm.coe.int/1680306052 [last viewed October 12, 2019].

21 A decade ago, the fifteen Member States of the EU set a strategic goal for the EU "to become the most dynamic and competitive, knowledge-based economy in the world, capable of sustaining economic growth, employment and social cohesion" (conclusions of the European Council of March 2000), see Lisbon Strategy, in Investing in European Research, Towards 3 \% of GDP. Available at: http://ec.europa.eu/invest-in-research/action/history_en.htm [last viewed October 12, 2019], and Article 114 paragraphs 3 and 5 of the Consolidated Version of the Treaty on the Functioning of the European Union, OJ C 326, 26.10.2012, pp. 47-390, OJ C 326, 26.10.2012, pp. 47-390 (GA). Available at: https://eur-lex.europa.eu/legal-content/EN/TXT/?uri=celex\%3A12012E\%2FTXT [last viewed October 12, 2019].

Within the EU operates the European Commission's Scientific Advice Mechanism. Starting from 1980s, the Europe's Framework Programmes as a key element of research policy in Europe became operational. See Deighton B. O'Donnell P. Europe's Framework Programmes - a key element of research policy in Europe. Available at: https://horizon-magazine.eu/article/europe-s-frameworkprogrammes-key-element-research-policy-europe.html [last viewed October 20, 2019]. 
societal and economic. ${ }^{22}$ This approach, although not fully conceptualized within the EU, fits into the role of legal science put forward by the paper.

Apart from that requirement, the European Commission in its Recommendation of 2005 encourages both geographical and inter-sectoral mobility in the career appraisal and career advancement systems for researchers. ${ }^{23}$ According to this recommendation, the inter-sectoral mobility is a change from one discipline or sector to another, whether as part of the initial research training or at a later stage of the research career. We find the inter-sectoral mobility is of key importance for strengthening societal and economic impact of legal science.

However, although expressly encouraged by EU soft acquis, the concept of intersectoral mobility remained out of the scope of the scrutiny, which was conducted over the Serbian compliance with the requirements from the Chapter 25 - Science and Research. Namely, the EU provisionally closed Chapter 25 in the case of Serbia without requiring the benchmarks for its provisional closure. It stressed the general good level of Serbia's state of preparedness in the area of science and research and pointed to the limited scope and particular nature of acquis obligations in this chapter. In doing so, the EU failed to take into consideration the Serbian lack of alignment with the EU inter-sectoral mobility standards.

EU annual reports on Serbia for 2018 and 2019 are slightly more progressive, as they underline that Serbia still has to stimulate more intense cooperation between industry and academia, in line with the respective national research strategy. ${ }^{24}$ However, the inter-sectoral mobility is a broader notion than the intensified cooperation between industry and academia and as such it should include the cooperation with various other sectors of society beyond the industry. This particularly applies to the legal science, whose economic and societal impacts significantly transcends the industry. Furthermore, the notion of cooperation should be interpreted broadly to include the researcher's transfer from one sector to another

22 See Commission Proposal for the Next EU Research \& Innovation Programme (2021-2027), Hartung H. Inclusive Society, Impact of SSH for a European Research Agenda 28/11/2018, Vienna. Available at: https://www.ssh-impact.eu/wp-content/uploads/2018/12/Contributions-of-SSHto-the-topic-Inclusive-and-Secure-Society-focus-Inclusive-Society_Harald_Hartung.pdf [last viewed October 20,2019].

23 Recitals 11 and 12 of the Commission Recommendation of 11 March 2005 on the European Charter for Researchers and on a Code of Conduct for the Recruitment of Researchers. Official Journal, L 75, 22.3.2005, pp. 67-77. It guarantees that such an experience is conducive to their professional development.

24 Commission Staff Working Document, Serbia 2018 Report, Accompanying the document, Communication from the Commission to the European Parliament, the Council, the European Economic and Social Committee and the Committee of the Regions, 2018 Communication on EU Enlargement Policy $\{\operatorname{COM}(2018) 450$ final $\}$ Strasbourg, 17.4.2018 SWD(2018) 152 final, p. 76. Available at: https://ec.europa.eu/neighbourhood-enlargement/sites/near/files/20180417-serbiareport.pdf [last viewed October 12, 2019]; Commission Staff Working Document, Serbia 2019 Report, Accompanying the document, Communication from the Commission to the European Parliament, the Council, the European Economic and Social Committee and the Committee of the Regions, 2019. Communication on EU Enlargement Policy $\{\mathrm{COM}(2019) 260$ final $\}$, Brussels, 29.5.2019 SWD(2019) 219 final, p. 82. Available at: http://europa.rs/wp-content/ uploads/2019/05/Commission-Staff-working-document-Serbia-annual-report-2019.pdf [last viewed October 12, 2019]. 
in order to be in line with the concept of inter-sectoral mobility, which currently is not the case. Apparently, the EU took the lenient and unsystematic approach when scrutinizing the alignment of Serbian scientific policies with the acquis. That may have detrimental effects on the development of Serbian scientific policies, as well as on its expected economic and social impact.

\section{Concept of science in the context of Serbian national standards}

Serbian regulatory framework on science has recently undergone significant changes. They were initiated by the adoption of the new national research strategy for the period of 2016-2020 25 and followed by the recent adoption of Law on the Science Fund of the Republic of Serbia ${ }^{26}$ and the Law on Science and Research. ${ }^{27}$ While some changes are considered as "a right step in the right direction" ${ }^{28}$, others could rather be assessed as drawbacks, which are in sharp contrast with the desired model of providing strategic incentives for a prominent role of legal science in impacting the society and economy. The result raises mixed feelings, as the mission to remodel the science and research policy is completed, but the absence of a systemic approach is notable. In order to assess the success of the undertaken scientific reform, it is important to examine its different aspects.

\subsection{Improved national strategic goals are partly reflected in the new legislation}

Some initial improvements were envisaged even by the previous national research strategy of 2010, which holds that social sciences do constitute a necessary support of all reform processes in the society. ${ }^{29}$ This strategy affirmed the role of social sciences in public policy development through systematic cooperation between SROs and public policy makers as one of research priorities in the field of

25 It is named Research for Innovation Strategy (2016-2020). Official Gazette of the RS, No. 25 of 9 March 2016. Available at: www.pravno-informacioni-sistem.rs/Sl GlasnikPortal/eli/rep/sgrs/ vlada/strategija/2016/25/1/reg [last viewed October 15, 2019].

26 Law on the Science Fund of the Republic of Serbia. Official Gazzette of the RS, No. 95/2018. Available at: https://www.paragraf.rs/propisi/zakon-o-fondu-za-nauku-republike-srbije html [last viewed October 15, 2019].

27 The previous key legal act titled the Law on Scientific Research Activities became overshadowed by the two recently adopted law and most of its provisions are set apart. See Law on Science and Research. Official Gazette of the RS, No. 49/2019. Available at: http://www.pravno-informacionisistem.rs/SlGlasnikPortal/eli/rep/sgrs/skupstina/zakon/2019/49/1/reg [last viewed October 16, 2019].

28 Tatalovic M. Serbia passes controversial science reforms to modernize research. Available at: https:// www.chemistryworld.com/new.s/serbia-passes-controversial-science-reforms-to-moderniseresearch-/3010733.article?adredir=1 [last viewed October 16, 2019.]

29 Strategy of Scientific and Technological Development of the Republic of Serbia. Official Gazette of the RS, No. 13/2010. Available at: http://demo.paragraf.rs/demo/combined/Old/t/t2010_03/ t03_0227.htm [last viewed October 10, 2019]. 
social sciences. In addition, it pointed to the key role of social sciences in supporting the EU integration process and development of negotiation platforms. ${ }^{30}$ Similar wording is reiterated in the current research strategy (2016-2020). ${ }^{31}$ Both strategies are advanced as they refer to the direct link between the scientific research and the economic and social development. Although both are aimed toward improving mobility of researchers, the new strategy is more advanced than the previous one, as it refers explicitly to inter-sectoral mobility in addition to geographical one. ${ }^{32}$

All the elaborated strategic goals were mostly successfully implemented in in the general provisions of the recently adopted laws which regulate the goals of scientific research activities. ${ }^{33}$ Both laws refer to the needed cooperation between the science and the economy, although they not fully implement the mobility requirement. ${ }^{34}$ The introduced statutory obligation of the SROs to strengthen the process of evidence-based public policy and law making is also a positive example. ${ }^{35}$

\subsection{Introducing mixed funding system of science}

In contrast to the previous system of exclusive project funding of SROs, the new laws provide for a mixed funding system, combining project funding through the Science Fund and other avenues with institutional funding. ${ }^{36}$ It is early to assess the results of the new system, as it will not become operational before 2020 . The key positive development of the new funding system is that the same goals related to the mobility and the social and economic impact of the scientific activities have to be achieved regardless of whether the project or institutional funding is applied. Hence, although the institutional funding requires programmes adopted for a seven-year

30 Strategy of Scientific and Technological Development of the Republic of Serbia. Official Gazette of the RS, No. 13/2010. Available at: http://demo.paragraf.rs/demo/combined/Old/t/t2010_03/ t03_0227.htm [last viewed October 10, 2019].

31 However, the new Strategy, opposite to the previous one fails to mention the role of science in the EU integration process.

32 The new strategy expressly recognizes that the inter-sectoral mobility does not exists in the Republic of Serbia and comes up with certain proposals for its introduction. See Research for Innovation Strategy (2016-2020), p. 11.

33 See Articles 3 and 20 of the Law on the Science Fund of the Republic of Serbia and Articles 3 and 8 of the Law on Science and Research.

34 While the provisions on mobility are not explicitly introduced in the Law on the Science Fund of the Republic of Serbia, the Law on Science and Research refers to general notion of mobility but in an insufficiently clear manner.

35 Article 9 paragraph 1 point 7 of the Law on Science and Research.

36 See Articles 106 and 107 of the Law on Science and Research. 
period, the SROs are bound to update and modify their programmes as to make sure that formulated strategic goals are met in each particular case. ${ }^{37}$

Finally, one of main shortcomings of the previous and current legal system is the lack of mechanisms for the SROs to apply for donor projects on regulatory reforms. Although the new laws on science provides for that possibility in principle, other pieces of national legislation are not sound in that regard. Moreover, most of international organizations which are in favour of making links between science and regulatory reforms do not have calls in the area of regulatory reform which would allow SROs to apply for them.

\subsection{Misconception about certain science-related notions}

In line with the offered concept of legal science, the Law on Science and Research rightly recognizes the interconnectivity between scientific and other non-scientific sectors, insisting, among others, on the systemic cooperation among different institutions. In a similar vein, the current research strategy and the Law on Science and Research require the excellence of scientific research and its relevance for the economic and social development. ${ }^{38}$

However, the envisaged cooperation among institutions is wrongly understood and implemented by national lawmakers. For instance, its implementation by the Law on Ministries may undermine the achievement of the values of relevance and excellence of scientific research. That law stipulates that line ministries within their purview give preliminary consent for the allocation of funds from the state budget to SROs which are established in the areas falling under their purview for the realization of programmes of public interest. ${ }^{39}$ It seems that this provision hinders the development of science which should rather impact the society without letting the national authorities have full control over the research ideas and activities of SROs.

37 See Article 9 of the Law on Science and Research. Furthermore, the new funding system envisages that the research spending in the coming years will be significantly increased. Although the increased budged allocations will apparently foster the scientific work with a potential to strengthen its impact, some doubts still remain. Most representatives of the scientific community remain sceptical given that envisaged reforms implying increased budget allocations will do nothing for scientists who do not currently have a job. See Tatalovic M. Serbia passes controversial science reforms to modernize research.

38 On the other hand, the Law on the Science Fund of the Republic of Serbia requires only excellence of the project idea, probably unintentionally omitting the needed relevance. See Article 23 of the Science Fund of the Republic of Serbia.

39 In addition, it states that line ministries participate in supervising national scientific research organizations over their spending of the dedicated funds. See Article 22 of the Law on Ministries. Official Gazette of the RS, No. 44/2014, 14/2015, 54/2015, 96/2015 and 62/2017. Available at: https://www.paragraf.rs/propisi/zakon_o_ministarstvima.html [last viewed October 12, 2019]. 
The national framework did not properly implement EU standards on the expected societal and economic impact of the research projects. ${ }^{40}$ Although the Law on Science and Research introduces the achieved impact as one of criteria for the evaluation of the work of SROs, this legislation fails to properly define it. It wrongly states that impact amounts to "visibility and recognition of the institution in the society", which may further create confusion on behalf of SRO as to formulating the successful research ideas, while cynics could see it as an invitation for selfmarketing. ${ }^{41}$

The current legal framework also missed to fully take into the account the EU standards on inter-sectoral mobility envisaged by the aforementioned recommendation. ${ }^{42}$ Although the given recommendation encourages national authorities to recognize inter-sectoral mobility as a valuable contribution to the professional development of researchers, Serbian law is very restrictive on that issue. The Law on Science and Research could have been a good opportunity to address inter-sectoral mobility in the national legislation, but that opportunity was missed. The new law does not provide sufficiently extensive grounds to enable provisional mobility for the researchers from one sector to another. ${ }^{43}$ It only leaves room for the inter-sectoral mobility by expressly allowing unpaid leave for researchers from SROs in case of taking up of public office, while younger researchers whose experience qualifies them for taking only lower positions in the public sector are not allowed a provisional change from one sector to another.

\subsection{Legal scholars, scientific reform and regulatory development in Serbia: a cross-section of the current state of affairs}

In the context of achieving desired impact, the following sets of activities of legal scholars are of key importance: activities toward improving policy development, activities toward improving legal drafting process, and activities toward improving judicial decision-making. Serbian regulatory framework failed to provide equal incentives for those sets of activities. Instead, it has unreasonably favoured some of them at the expense of others. This clearly shows that the scientific reform in Serbia was not conducted in a systematic manner.

Firstly, while the current framework does not provide any incentive for scholars who participate in working groups for legal drafting, the opposite is true

\footnotetext{
40 According to the Commission, the societal impact of research should be visible in developing, supporting and implementing EU policies and addressing global challenges, while the economic impact mostly relates to strengthening market deployment of innovative solutions.

41 See Article 110 of the Law on Science and Research.

42 Commission Recommendation of 11 March 2005 on the European Charter for Researchers and on a Code of Conduct for the Recruitment of Researchers, Official Journal, L 75, 22.3.2005, pp. 67-77.

43 See Articles 100 and 101 of the Law.
} 
for scholars who engage in creation of public policy documents. ${ }^{44}$ The reason behind the introduction of different regimes remained unclear. The introduction of specific incentives for scholars who take part in working groups drafting legislation would be of utmost importance for the quality of legal drafts, especially when it comes to the demanding legislative tasks Serbia must fulfil in the EU accession process. The existing incentives for legal scholars to participate in public policy document preparation seem weak and therefore should be strengthened. The model for performance assessment of researchers is still driven by the "publish or perish" paradigm; even though development of policy documents and regulatory impact assessments qualify as scientific contributions, their valuation is disproportionate compared to writing of scientific papers, and is not a relevant factor for advancement of academic career. Furthermore, for the time being these incentives are applicable only in case when certain public policy documents are adopted. That regime obliterates the efforts invested by diligent legal scholars, which at times have not been accepted merely due to politically driven reasons. ${ }^{45}$ The government also lacks a systemic or proactive approach towards including legal academics in regulatory reform. Publicly available data shows very low participation of legal scholars in working groups for legal drafting and policy making, which undermines the quality of those processes. ${ }^{46}$ The practice of having on average only one or no scholars in a working group disables fruitful discussion on different conceptions among respective members.

Furthermore, the practice of participation of legal scholars in various associations gathering legal operators and scholars is neither sufficiently developed nor supported through specific incentives for scholars. For instance, although the National Network on European Judicial Protection of Human Rights was founded to facilitate the interpretation and application of the European Convention on Human Rights through fostering dialogue between holders of judicial offices

44 The given public policy documents include strategies, analysis of public policies and impact analyses. See Applicable national rulebook governing the performance assessments of researchers from SROs including faculties.

45 The criteria for performance assessment of researchers are elaborated in the Rulebook on Procedure, Method of Assessment and Quantitative Expression of Researchers' Scientific Results. Official Gazette of the RS, No. 24/2016, 21/2017, 38/2017. Available at: http://www.pravno-informacionisistem.rs/SlGlasnikPortal/eli/rep/sgrs/ministarstva/pravilnik/2016/24/1/reg [last viewed October 14, 2019].

46 For instance, the working group tasked with developing the Draft Law on State Aid has no lawyers from academia. (Decision on Establishment of Working Group for Drafting the Law on State Aid. Official Gazette of the RS, No. 102/2018). The working group for developing the text of the National Judicial Development Strategy has two members from the academia among its 30 members (Ministry of Justice Ruling No. 119-01-23/2019-06 of January 22, 2019); Working Group for Developing the Draft Law on Amendments to the Law on Judicial Academy has no legal scholars amongs its 11 members (Ministry of Justice Ruling No. 119-01-00238/2018-06 of January 22, 2019). The working group tasked with drafting the amendments to the Law on Judges, Law on Organisation of Courtsa and Law on High Judicial Council has one lawyer from the acadamia among its 11 members (Ministry of Justice Ruling No. 119-01-00235/2018-06 of January 22, 2019). 
and legal scholars, it was not sustainable enough to accomplish that goal. ${ }^{47}$ The lack of adequate funding along with the lack of other incentives for legal scholars to participate in that platform in practice is reflected by scarce participation. ${ }^{48}$

Finally, there are discrepancies between the incentives provided for legal scholars who work as professors at the Faculty of Law and legal scholars working at other SROs. They discourage those affiliated to other SROs to contribute to judicial decision-making. In contrast to law professors who are in parallel allowed to sit as Constitutional Court judges, the other legal scholars are not even entitled for unpaid leave if they become Constitutional Court judges. This unequal treatment of different categories of legal scholars proves unsystematic approach taken by Serbian law makers to the science reform.

\section{Conclusions}

The view advocated by natural law thinkers, according to which legal doctrine shall be perceived as a source of law instead of a mere wellspring of inspiration, was not implemented either in Serbia or in most of the contemporary national legal systems. ${ }^{49}$ This apparently undermines the position of the legal science within the national legal systems and requires additional actions to be taken at international, supranational or at least national fora. Those actions should be directed towards improved valorisation of contributions of legal scholars in the field of regulatory reform. In the context of Serbia, even though Serbian national supporters of natural law developed the Hexagon over thirty years ago, during the communism era, having gathered numerous legal scholars, their calls for a clear and systemically proactive role of legal science in spearheading regulatory reforms so far have not been fully locally recognized in practice. ${ }^{50}$ As shown above, the reach of legal science in providing substantive contributions to regulatory reform is still limited in Serbia.

47 Available at: https://www.pars.rs/images/projekti/JAP/komponenta-1/Strategic-plan-for-theNational-network-on-European-judicial-protection-of-human-rights-in-Serbia-Strateki-planza-Nacionalnu-mreu-o-evropskoj-sudskoj-zatiti-ljudskih-prava-u-RS.pdf [last viewed October 11, 2019].

48 When it comes to associations which foster the legal science contribution to regulatory reform, the German association "Deutscher Juristentag e.V." may serve as the best practice example in that regard. It brings together lawyers from all parts of the country to investigate on a scientific basis needs for changes of the legal system, and present proposals for the legal development. The Deutscher Juristentag e.V. is a registered association with around 5000 members. Available at: www.djt.de [last viewed October 11, 2019].

49 See, inter alia, Buchanan K. The Role of the "Doctrine" as a Source of Law in France, December 20, 2010. Available at: https://blogs.loc.gov/law/2010/12/the-role-of-the-doctrine-as-a-source-oflaw-in-france/ [last viewed December 17, 2019]; Papaux A. Wyler E. Legal Theory as a Source of International Law: Doctrine as Constitutive of International Law. In: The Oxford Handbook of the Sources of International Law, Besson S., d' Aspremont J. (eds.), Oxford: Oxford University Press, 2018, pp. 513-541.

50 Perovic S. Neprolaznost Heksagona prirodnog prava. In: Besede sa Kopaonika [Timeless Hexagon of Natural Law. In: Speeches from Kopaonik], 2001, p. 320. 
Furthermore, it can be stated that neither international nor Serbian regulatory framework provides sufficient incentives for strengthening the societal and economic impact of legal science. There are certain soft law standards at international and supranational levels governing legal science, while the key problem is a lack of hard law instruments in the field. Although the EU scrutiny during the negotiation process should include control over the fulfilment of its soft law standards, that was not the case for Serbia. Apparently, the applied lenient scrutiny by the European Commission was to an extent enabling towards the national unsystematic approach with regard to legal science reform in Serbia.

Apparently, international and national standards are not fully in line with the broad concept of legal science and its expected contribution to regulatory reform proposed in this paper. Namely, the authors departed from the view taken by the defenders of the argumentativist model stating that primary role of legal scholars is to offer practical solutions for legal disagreements and the theory of legisprudence underlining that, in order to properly resolve a social problem, a regulatory act must be underpinned by legal science. Furthermore, Barker pointed to the importance of social impact which has to be achieved by legal scholars. However, it seems that their views do not provide sufficient indicators for assessing the real impact made by activities of legal scholars. They narrowly understood social impact by limiting it to the insufficiently determined contribution to judicial decision-making, fostering knowledge and understanding among non-lawyers. ${ }^{51}$ On the contrary, we find that their main impact-related contribution should be primarily linked to strengthening capacities of legal community in three different areas: law-making process, policymaking process, as well as judicial decision-making at national, supranational and international levels.

Therefore, it is of particular importance that the notion of expected impact that legal science should make is thoroughly elaborated on the theoretical level. After its conceptualization, the given notion should be more systematically followed in practice. Upon embarking on that road, we offer three different sets of activities that should be clearly included in the notion of legal science and consequently valorised as contributions of legal scholars to the social and economic development. These are activities toward improving policy development; activities toward improving legal drafting process, and activities toward improving judicial decision-making process. Their results should be visible in the strengthened participation of legal scientists in working groups and associations for regulatory reforms, developed platforms for improving national and supranational jurisprudence, and through improved mobility of legal operators and legal scholars among sectors. Unless adequate incentives for legal scholars to make the expected impact become available in Serbia and worldwide, it seems that parallel development of society and legal science will be constantly undermined.

51 See, inter alia, Barker S. 2018, pp. 15-16. 


\section{BIBLIOGRAPHY}

\section{Literature}

1. Aarnio A. The Rational as Reasonable. Dordrecht: Kluwer, 1987.

2. Alexy R. The Special Case Thesis. Ratio Juris, 1999, Vol. 12, No. 4, pp. 374-384.

3. Barker S. Exploring the Development of a Standard System of Citation Metrics for Legal Academics. Canadian Law Library Review, Vol. 43, No. 2, 2018, pp. 11-20.

4. Ciencia Jurídica A. In: El derecho y la Justicia, Ernesto Garzón Valdés and Francisco Laporta (eds.), Madrid: Trotta, 1996.

5. Dajović G. Proučavanje prava - pravna nauka, teorija i filozofija [Study of the Law: Legal Science, Legal Theory and Philosophy of Law]. Pravni zapisi [Review], No. 2, 2017, pp. 222-248.

6. Ferrajoli L. Principia Iuris. Roma: Laterza, 2007.

7. Jori M. Il Metodo Giuridico. Milano: Milano, 1976.

8. Núñez Vaquero A. Five Models of Legal Science. Revus, No. 19, 2013, pp. 53-81.

9. Papaux A. Wyler E. Legal Theory as a Source of International Law: Doctrine as Constitutive of International Law. In: The Oxford Handbook of the Sources of International Law. Besson S., d’Aspremont J. (eds.), Oxford: Oxford University Press, 2018, pp. 513-541.

10. Peczenik A. Scientia Juris. Dordrecht: Springer, 2005.

11. Santiago Nino C. Algunos Modelos Metodológicos de 'Ciencia' Jurídica. México City: Fontamara - UNAM, 1999.

12. Seidman R. B. Between Policy and Implementation: Legislative Drafting for Development. In: Drafting Legislation. A Modern Approach. Constantin Stefanou and Helen Xanthaki (eds.), Ashgate e-Book: London, 2008, pp. 287-320.

13. Tamayo Salmerón R. El derecho y la ciencia del derecho. Mexico, UNAM, 1986.

14. Wintgens J. The Theory and Practice of Legislation: Essays in Legisprudence. Aldershot: Ashgate, 2005.

\section{Legislative acts}

1. Law on Ministries [Закон о министарствима] Official Gazette of the RS, No. 44/2014, 14/2015, 54/2015, 96/2015 and 62/2017. Available at: https://www.paragraf.rs/propisi/ zakon_o_ministarstvima.html [last viewed October 12, 2019].

2. Law on the Science Fund of the Republic of Serbia [Закон о Фонду за науку Републике Србије]. Official Gazette of the RS, No. 95/2018. Available at: https://www.paragraf.rs/ propisi/zakon-o-fondu-za-nauku-republike-srbije html [last viewed October 15, 2019].

3. Law on Science and Research [Закон о науци и истраживањима]. Official Gazette of the RS, No. 49/2019. Available at: http://www.pravno-informacioni-sistem.rs/SlGlasnikPortal/eli/ rep/sgrs/skupstina/zakon/2019/49/1/reg [last viewed October 16, 2019].

4. Ministry of Justice Ruling No. 119-01-23/2019-06 of January 22, 2019.

5. Ministry of Justice Ruling No. 119-01-00238/2018-06 of January 22, 2019.

6. Ministry of Justice Ruling No. 119-01-00235/2018-06 of January 22, 2019.

7. Statute of the Council of Europe. Council of Europe London, 5.V.1949, European Treaty Series-No. 1. Available at: https://rm.coe.int/1680306052 [last viewed October 12, 2019]. 


\section{Other sources}

1. Buchanan K. The Role of the "Doctrine" as a Source of Law in France, December 20, 2010. Available at: https://blogs.loc.gov/law/2010/12/the-role-of-the-doctrine-as-a-source-of-lawin-france/ [last viewed October 17, 2019].

2. Consolidated Version of the Treaty on the Functioning of the European Union, OJ C 326, 26.10.2012, pp. 47-390, OJ C 326, 26.10.2012, pp. 47-390 (GA). Available at: https:// eur-lex.europa.eu/legal-content/EN/TXT/?uri=celex\%3A12012E\%2FTXT $\quad$ last viewed October 12, 2019].

3. Commission Proposal for the Next EU Research \& Innovation Programme (2021-2027), Hartung H. Inclusive Society, Impact of SSH for a European Research Agenda 28/11/2018, Vienna. Available at: https://www.ssh-impact.eu/wp-content/uploads/2018/12/Contributions-of-SSH-to-the-topic-Inclusive-and-Secure-Society-focus-Inclusive-Society_Harald_ Hartung.pdf [last viewed October 20, 2019].

4. Commission Recommendation of 11 March 2005 on the European Charter for Researchers and on a Code of Conduct for the Recruitment of Researchers, Official Journal, L 75, 22.3.2005, pp. 67-77.

5. Commission Staff Working Document, Serbia 2018 Report, Accompanying the document, Communication from the Commission to the European Parliament, the Council, the European Economic and Social Committee and the Committee of the Regions, 2018 Communication on EU Enlargement Policy $\{\operatorname{COM}(2018) 450$ final $\}$ Strasbourg, 17.4.2018 $\operatorname{SWD(2018)} 152$ final, Available at: https://ec.europa.eu/neighbourhood-enlargement/sites/ near/files/20180417-serbia-report.pdf [last viewed October 12, 2019].

6. Commission Staff Working Document, Serbia 2019 Report, Accompanying the document, Communication from the Commission to the European Parliament, the Council, the European Economic and Social Committee and the Committee of the Regions, 2019. Communication on EU Enlargement Policy $\{\operatorname{COM}(2019) 260$ final\}, Brussels, 29.5.2019 SWD(2019) 219 final, p. 82. Available at: http://europa.rs/wp-content/uploads/2019/05/Commission-Staffworking-document-Serbia-annual-report-2019.pdf [last viewed October 12, 2019].

7. Decision on establishment of Working group for Drafting the Law on State Aid. Official Gazette of the RS, No. 102/2018.

8. Deighton B. O'Donnell P. Europe's Framework Programmes - a key element of research policy in Europe. Available at: https://horizon-magazine.eu/article/europe-s-frameworkprogrammes-key-element-research-policy-europe.html [last viewed October 20, 2019].

9. Lisbon Strategy, in Investing in European Research, Towards 3 \% of GDP. Available at: http:// ec.europa.eu/invest-in-research/action/history_en.htm [last viewed October 12, 2019].

10. Perovic S. Neprolaznost Heksagona prirodnog prava [Timeless Hexagon of Natural Law]. In: Besede sa Kopaonika [Speeches from Kopaonik], 2001, p. 299. Available at: https://kopaonikschool.org/wp-content/uploads/2019/05/BESEDE-2001.pdf [last viewed December 10, 2019].

11. Research for Innovation Strategy (2016-2020) [Стратегија научног и технолошког развоја Републике Србије за период оА 2016. Ао 2020. године - Истраживања за иновације]. Official Gazette of the RS, No. 25 of 9 March 2016. Available at: www.pravno-informacionisistem.rs/Sl GlasnikPortal/eli/rep/sgrs/vlada/strategija/2016/25/1/reg $\quad[$ last viewed October 15, 2019]. 
12. Regulatory Policy Overlook 2018. Available at: https://www.oecd.org/gov/regulatorypolicy/oecd-regulatory-policy-outlook-2018-9789264303072-en.htm [last viewed October $15,2019]$.

13. Rulebook on Procedure, Method of Assessment and Quantitative Expression of Researchers' Scientific Results [Правилник о поступку, начину вредновања и квантитативном исказивању научноистраживачких резултата истраживача]. Official Gazette of the RS, No. 24/2016, 21/2017, 38/2017. Available at: http://www.pravno-informacioni-sistem.rs/ SlGlasnikPortal/eli/rep/sgrs/ministarstva/pravilnik/2016/24/1/reg [last viewed October $14,2019]$.

14. Strategy of Scientific and Technological Development of the Republic of Serbia [Стратегија научног и технолошког развоја Републике Србије за периоА оА 2010. оА 2015. године]. Official Gazette of the RS, No. 13/2010. Available at: http://demo.paragraf.rs/demo/ combined/Old/t/t2010_03/t03_0227.htm [last viewed October 10, 2019].

15. Tatalovic M. Serbia passes controversial science reforms to modernize research. Available at: https://www.chemistryworld.com/new.s/serbia-passes-controversial-science-reforms-tomodernise-research-/3010733.article?adredir=1 [last viewed October 16, 2019].

16. Transforming Our World: the 2030 Agenda for Sustainable Development. Resolution adopted by the General Assembly on 25 September 2015 [without reference to a Main Committee (A/70/L.1)].

17. Vasić R. Pravna država i vladavina zakona: Šta pravna teorija poručuje nomotehnici. In: Nomotehnika i pravničko rasuđivanje [Vasić R. Legal State and Rule of Law: What Are the Messages Sent by the Legal Science to the Nomotechnics. In: Nomotechnics and Legal Reasoning] Radmila Vasić, Marko Stanković (eds.). UNDP i Pravni fakultet Univerziteta u Beogradu, 2018, pp. 17-67. Available at: https://www.rs.undp.org/content/dam/serbia/ Publications\%20and\%20reports/Serbian/DobraUprava/undp_rs_Nomotehnika_Maj2018. pdf [last viewed October 16, 2019]. 